\title{
TUJOM

\section{EXPLORING FACTORS AFFECTING CONSUMERS' INTENTION TOWARD PURCHASING IMITATION JEWELRY: AN EXTENSION OF THEORY OF PLANNED BEHAVIOR}

Samir DAS ${ }^{1}$

Md. Mahiuddin SABBIR ${ }^{2}$
Received Date (Başvuru Tarihi): 29/10/2019

Accepted Date (Kabul Tarihi): 22/11/2019

Published Date (YayınTarihi): 26/12/2019
ABSTRACT

Keywords:

Extended Theory of Planned Behavior (ETPB), Fashion Innovativeness and Purchasing Imitation Jewelry

JEL Codes: M31, M39
This study examines the influencing factors those affect Bangladeshi consumers' attitude and intention towards purchasing imitation jewelry through the conceptual extension of a theoretical model known as Theory of Planned Behavior (TPB). The authors proposed an Extended Theory of Planned Behavior (ETPB), consisting of seven factors: attitude, subjective norms, perceived behavioral control, product knowledge, value consciousness, fashion innovativeness and behavioral intention. Structural Equation Modeling (SEM) was employed to measure the impacts of the constructs that were analyzed in the study via AMOS 23. The results of the analysis provided empirical evidence for the hypotheses suggesting that value consciousness is more important than fashion innovativeness in influencing consumer attitude towards purchasing imitation jewelry. Furthermore, attitude, subjective norms, perceived behavioral control and product knowledge have significant impact on consumer intention towards purchasing imitation jewelry. Based on what emerged from the analysis, the study has suggested interesting theoretical and managerial implications.

\section{TÜKETICILERIN TAKLIT MÜCEVHERAT SATIN ALMA NIYETINİ ETKILEYEN \\ FAKTÖRLERİ KEŞFETME: PLANLI DAVRANIŞ TEORISIININ GENIŞLEMESİ}

\section{$\ddot{O} Z$}

Anahtar Kelimeler: Genişletilmiş Planlı Davranış Teorisi (ETPB); Moda Yenilikçiliği, Imitasyon Takı Satın Alma

JEL Kodlart:

M31, M39
Bu çalıșma, Bangladeșli tüketicilerin Planlı Davranış Teorisi (TPB) olarak bilinen teorik bir modelin kavramsal olarak genişletilmesi yoluyla taklit mücevher satın alma konusundaki tutum ve niyetini etkileyen faktörleri incelemektedir. Yazarlar, şu yedi faktörden oluşan Genişletilmiş Planlı Davranış Teorisi'ni (ETPB) önermişlerdir: tutum, öznel normlar, algılanan davranış kontrolü, ürün bilgisi, değer bilinci, moda yenilikçiliğ $i$ ve davranışsal niyet. Faktörlerin etkilerini ölçmek için Yapısal Eşitlik Modellemesi'ne (YEM) başvurulmuş, AMOS 23 programı kullanılmıştır. Analiz sonuçları, taklit mücevher satın almaya yönelik tüketici tutumunu etkilemede değer bilincinin moda yenilikçiliğinden daha önemli olduğunu göstermektedir. Ayrıca, tutum, öznel normlar, algılanan davranış kontrolü ve ürün bilgisi de tüketicilerin taklit mücevher satın almaya yönelik niyetleri üzerinde önemli bir etkiye sahiptir. Çalışma, analizden sonuçlarına dayanarak, ilginç teorik ve yönetimsel uygulamalar önermiştir.

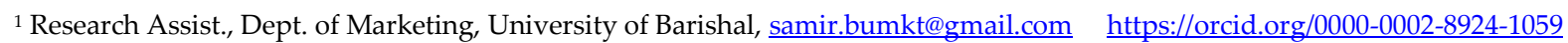
${ }^{2}$ Assist. Professor, Dept of Marketing, University of Barishal, mmsabbir@bu.ac.bd 


\section{INTRODUCTION}

Jewelry is one of the most ancient and enduring forms of personal expression and ornamentation. Necklaces, rings, earrings, and bracelets are some of the most common types of jewelry. Jewelry made from precious metals and gemstones falls within the personal luxury goods but fashion jewelry or imitation jewelry is typically made from inexpensive materials (MarketWatch, 2019). The imitation jewelry effect resembles the precious metal like gold, diamond, silver and platinum jewelry and people often call such imitation jewelry as fashion jewelry (Krijger, 2015). Imitation jewelry has been made of cut and uncut stones, plastic beads, cast iron, brass, nickel and other attractive materials (Sabbir, Hossain, \& Nomi, 2017). Globally, demand for imitation jewelry is increasing due to increasing cost of buying gemstones, diamonds, and solid gold and consumers are purchasing imitation jewelry to strike a balance between looking fashionable and maintaining budgets. But, increasing prices of raw materials, the shortage of skilled craftsmen and strict regulations are the major threats for this industry. China and India is the major manufacturer of imitation jewelry (Orendorff, 2019).

In Bangladesh, demand for imitation jewelry as fashion product is also increasing. Women like to wear fashion jewelry in different occasions including marriage ceremony, birthday party, Eid occasions and Christmas etc. Because it is comfortable, available, low cost and safe. Moreover, demand for imitation jewelry is increasing among married and unmarried women due to the changing perception and buying behavior of female consumers in urban areas. About $90-95 \%$ of all beautiful colored, gold plated, stone-embellished jewelry are made locally. The growing fashion consciousness among teens and cost effective fashionable jewelry is likely to boost the overall market in the coming years. The price of gold is much higher in Bangladesh compared to other international markets and gold users are gradually falling due to the rise in gold price and easy availability of cheaper gold-plated imitation jewelry and stone-made ornaments ("Jewellery sector in jeopardy", 2017). In spite of growth of consumption of imitation jewelry in Bangladesh in relation to the changes in society and economic trends, no research has been conducted yet addressing this issue. Considering the enormous potentials of this market, the key factors associated with Bangladeshi consumers' intention towards purchasing imitation jewelry need to be examined in order to expand the general understanding of the emerging market and develop appropriate marketing strategies that would enhance business success. To fill this gap in literature, this study aims to identify the factors those affect Bangladeshi consumers' attitude as well as intention towards 
purchasing imitation jewelry. The study contributes to the body of literature for global imitation jewelry industry by addressing the growing imitation jewelry market of Bangladesh.

\section{LITERATURE REVIEW}

It was predicted that market of global fashion jewelry would grow at the rate of $4.6 \%$ annually and was estimated to reach US \$185 billion by 2010 and US \$ 230 billion in 2015 (Bartleby, 2009). However, at present, it is growing at 5-6\% annually (Orendorff, 2019). Furthermore, global imitation jewelry market will grow over 7\% by 2023 (Research and Markets, 2018). Likewise, global imitation jewelry market size in 2015 was valued approximately at $\$ 25,500$ million and it is growing at a rate of $6.8 \%$ per annum to reach $\$ 43,700$ million by 2025 (Vogue Crafts and Design PVT Ltd., 2019). In many countries, imitation jewelry has become major contributor for their export. In 2006 export value of imitation jewelry was around USD 725 million which was about $10.51 \%$ of gross export value of china (Pan, 2008).

\subsection{An Overview Of Studies On Jewelry}

An empirical study was made by Sultana, Siddique, \& Islam (2015) on the analysis of consumer behavior in jewelry business found that operational and marketing, perceived quality and service quality and conformance quality are the major factors for consumers in purchasing jewelry. Krishnan \& Nandhini (2017) conducted a study on factors leading the working women to purchase gold jewelry and found that purity, quality, variety, word of mouth publicity, price, brand name, advertisement are leading factors in purchasing jewelry. In another study, Önder and Yeşilyurt (2012) found that being original, special design, authenticity, and having historical and mystical meaning were important features for women's appreciation of jewelry. The desire for wearing jewelry among Indian women is rising day by day giving a major push for the demand for imitation jewelry (Joseph, 2016). Besides, Joseph highlighted that imitation jewelry plays a significant role in the gold jewelry market and its sales. Sabbir et al. (2017) found that low cost of imitation jewelry, innovative and elegant design and matching with apparels significantly affect Bangladeshi women's preference of using imitation jewelry.

\subsection{Theory Of Planned Behavior And Fashion Goods}

Fishbein (1967) proposed the theory of reasoned action (TRA) to explain relationship between attitudes and behavior which is consisted of two key factors: attitude and subjective norms. But it had some limitations. Ajzen (1985) observed that theory of reasoned action was 
particularly applicable for describing behaviors when the behaviors were totally under volitional control. Furthermore, adoption of a given behavior requires opportunities, resources and skills. With an attempt to reduce those limitations, Ajzen (1991) proposed theory of planned behavior (TPB) with an extra construct namely perceived behavioral control to shape an individual's behavioral intentions and behavior. Many previous studies have used TPB model to identify the factors that affect the users' intentions to purchase counterfeit or imitated fashion products (Chang, 1998; Kim \& Karpova, 2010; Kwong \& Lee, 2002; Peace, Galletta, \& Thong, 2003; Penz \& Stottinger, 2005). Previous studies using TPB, found that the factors those have a significant effect on behavioral intention towards purchasing fashion goods are attitude, subjective norms and perceived behavior control (SelvanPerumal \& Sapihan, 2017; Kim \& Karpova, 2010). However, in another study Jain, Khan, \& Mishra (2017) found except perceived behavioral control, attitude and subjective norms have significant influence on behavioral intention.

In order to fully understand the behavioral intention of consumers related to fashion goods, O'Cass (2004) found knowledge about new fashion is important. Similarly, highlighted fashion knowledge as key contributor in consumption of fashion goods that creates the confidence in making purchase decision about fashion. Beside these, Riquelme, Abbas, \& Rios (2012) explored that value consciousness, norms and ethical consciousness influence attitude. Furthermore, in predicting attitude towards fashion goods a considerable number of studies in different contexts focused on fashion innovativeness (Park, Burns, \& Rabolt, 2007; Workman \& Caldwell, 2007) and value consciousness (Phau \& Teah, 2009; Toklu \& Baran, 2017).

However, this study differs from the previously mentioned studies, as it expands the range of factors that might impact on behavioral intention towards purchasing imitated fashion products; more specifically imitation jewelry within the context of Bangladesh. This is done through extending the TPB model with inclusion of product knowledge as a predictor of behavioral intention, fashion innovativeness and value consciousness as a predictor of attitude. Indeed, combining these variables with TPB is unprecedented in any study within the socioeconomic condition of Bangladesh. The new conceptual model can contribute to the current literature, as there is no existing study that adds product knowledge, fashion innovativeness and value consciousness with TPB model in order to examine the variations in behavioral intention in purchasing imitation jewelry. 


\section{THEORETICAL FRAMEWORK AND HYPOTHESIS DEVELOPMENT}

\subsection{Attitude (ATT)}

Attitude can be defined as the degree to which an individual has favorable or unfavorable evaluation about an object or appraisal of the behavior in question (Ajzen, 1991). But earlier researcher like Campbell (1947) defined attitude as a sort of behavioral coherence that an individual shows in respect to social objects. Later on, Allport (1967) considered attitude as a mental state which has direct or indirect influence on a person's responses to all objects and situations. Literature shows that there is a close relationship between ATT and behavioral intention and possibility to perform a particular behavior depends on the cost and benefits resulting from adopting the behavior (Cheng, Lam, \& Hsu, 2006). If the outcomes are positively evaluated, an individual tends to possess more favorable attitude and he or she is more likely to engage in that behavior (Ajzen, 1991; Cheng et al., 2006). Ajzen (1991) postulated that positive attitude towards a certain behavior strengthens an individual's intention to perform the behavior. In recent studies, it has been postulated that attitude has positive and significant influence on behavioral intention (Tommasetti et al., 2018; Efrat \& Shoham, 2013; Kim \& Han, 2010). Prior studies have demonstrated that attitude is a key determinant of behavioral intention to consume imitated products (Kim \& Karpova, 2010; Penz \& Stottinger, 2005). Based on what is described, the following hypothesis can be postulated:

H1: Attitude has positive and significant influence on consumer behavioral intention (CBI) towards purchasing imitation jewelry.

\subsection{Subjective Norms (SN)}

In TPB, SN is postulated as the second determinant of behavioral intention. Many authors highlighted this determinants as one of the most important determinant for accessing behavioral intention. Ajzen (1991) defined SN as social pressure that influence individuals to perform or not to perform a behavior. SN can also be defined as the pressure provided by those people who are important to the person performing the behavior by altering his or her perceptions, opinions, attitudes and behaviors (Schepers \& Wetzels, 2007). Park (2000) employed SN as perceived opinions of relatives, close friends, co-workers, business partners or others who are close and important for a person. SN is a series of pressures that are exerted by some individuals through influencing a person's intention to make a decision (Trafimow \& Fishbein, 1994). Eagly \& Chaiken (1993) described normative belief or SN as significance of 
others' influence in behavioral decision. So, the literature shows that $\mathrm{SN}$ is a significant determinant for accessing behavioral intention and role of $\mathrm{SN}$ as a determinant of behavioral intention is highlighted by many researchers (Baker, Gahtani, \& Hubona, 2007; Cheng et al., 2006; East, 2000; Laroche, Bergeron, \& Barbaro-Forleo, 2001). Thus, the following hypothesis is proposed:

H2: $\mathrm{SN}$ has positive and significant influence on $\mathrm{CBI}$ towards purchasing imitation jewelry.

\subsection{Perceived Behavioral Control (PBC)}

PBC refers to people's perception of the ease or difficulty of performing the behavior of interest (Ajzen, 1991). People often believe that they can perform a behavior when they have enough resources and opportunities to perform that behavior. And PBC, together with behavioral intention, can be used directly to predict behavioral achievement (Ajzen, 1991). In earlier studies, Bandura, Adams, \& Beyer $(1977,1980)$ found that behavioral intention is strongly influenced by a person's confidence in his or her ability to perform that behavior. In particular, $\mathrm{PBC}$ assesses the perception of how well one can control factors that may facilitate or constrain the actions needed to deal with a specific situation. As number of studies has been conducted to predict behavioral intention toward using PBC (Baker et al., 2007; Cheng et al., 2006; Conner \& Abraham, 2001; Taylor \& Todd, 1995), our study also included PBC to predict purchase intention towards imitation jewelry. For this reason, the following hypothesis can be postulated:

H3: $\mathrm{PBC}$ has positive and significant influence on CBI towards purchasing imitation jewelry.

\subsection{Product Knowledge (PK)}

PK can be defined as the knowledge of brands in terms of product class, product use context, product attribute knowledge, frequency of use and experience with fashion goods (Johnson \& Russo, 1984; Raju \& Reilly, 1980; Lastovicka, 1979). Knowledge can come from product experiences, ad exposure, interactions with sales people, friends, media, previous decision making or previous consumption and usage experiences held in memory (O'Cass, 2004). With regard to fashion goods, PK can be defined as how much a consumer actually knows about a product or how much a consumer thinks or perceives that they know about the product. In previous studies, O'Cass found that fashion knowledge influences consumer 
purchase decision about fashion goods. Therefore, in current study we propose the following hypothesis:

H4: PK has positive and significant influence on CBI towards purchasing imitation jewelry.

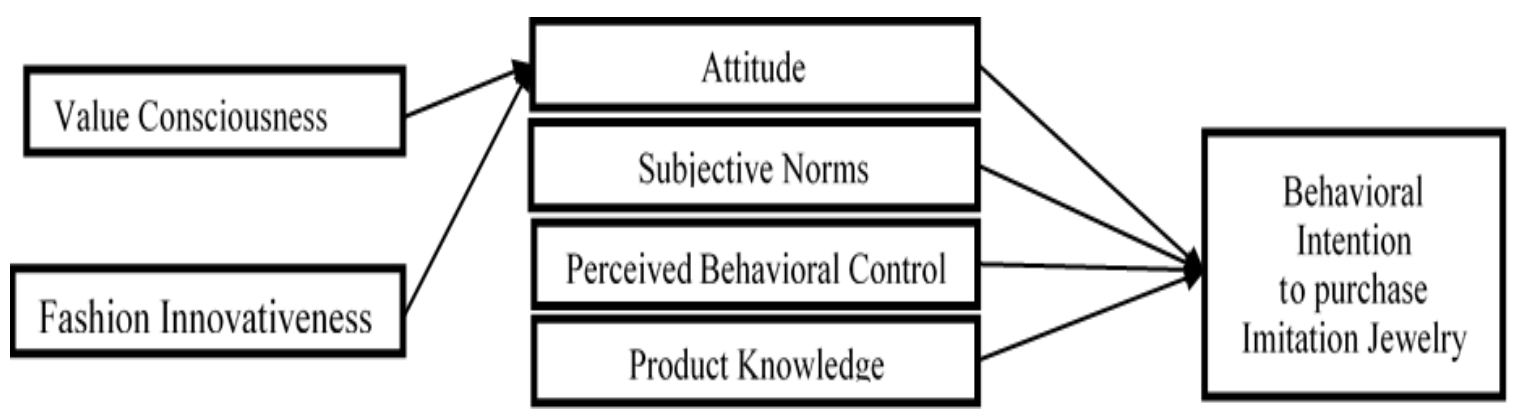

Figure 1: An Extended Theory of Planned Behavior (ETPB).

Source: Author's elaboration.

\subsection{Value Consciousness (VC)}

VC can be defined as the degree to which a consumer wants to pay low price with subject to some quality constraint (Ang, Cheng, Lim, \& Tambyah, 2001). As counterfeits of luxury brands usually provide same functional benefits as the original, they are perceived favorably (Phau \& Teah, 2009; Riquelme et al., 2012). Moreover, it was found that consumer get prestige and quality of branded products by purchasing imitate products and paying less (Bian \& Moutinho, 2009; Bloch et al., 1993; Grossman \& Shapiro, 1988; Tom, Garibaldi, Zeng, \& Pilcher, 1998). Later on, Riquelme et al. (2012) found that VC has a positive and significant effect on attitude to purchase imitated products. Therefore, value conscious consumers would have positive attitude towards counterfeits of luxury brands. We, therefore hypothesize that:

H5: VC has positive and significant influence on ATT towards purchasing imitation jewelry.

\subsection{Fashion Innovativeness (FI)}

Consumer innovativeness can be defined as the degree to which a consumer is willing to embrace new ideas, products, or services comparatively earlier than other people within a social system (Valente \& Rogers, 1995). In contrast to this definition, Rogers (1983) mentioned that fashion adoption process depends on two sub-processes: imitation and differentiation. According to Beaudoin \& Lachance (2006), fashion innovators always try to differentiate themselves whereas fashion follower carry out imitation role. Fashion innovators 
have some key characteristics, such as: they are more likely to read fashion magazines, prefer shopping more often, and buy more new fashion items (Beaudoin, Moore, \& Goldsmith, 2000; Jordaan \& Simpson, 2006; Workman \& Caldwell, 2007). Previous researchers found that FI is one of the most important factors that influence buying behavior and it has significant impact on attitude towards fashion products (Park et al., 2007). Imitation jewelry is a rising sector and we use FI as a determinant for analyzing consumers' attitude towards purchasing imitation jewelry. So, the following hypothesis can be postulated:

H6: FI has positive and significant influence on ATT towards purchasing imitation jewelry.

\section{METHODOLOGY}

\subsection{The Target Population}

The target population of this study was married and unmarried women. This consumer group accounts for huge proportion of the total number of consumers who are using jewelry. Moreover, this group of consumer are more conscious about fashion, as a result they consider imitation jewelry as a symbol of fashion. For this reason, practitioners are motivating to launch innovative imitation jewelry to meet continuous market demand.

\subsection{Sample Size And Sampling Technique}

For collecting data, convenience sampling technique was used. Because previous studies (Sultana, Siddique \& Islam, 2015; Park et al., 2007) found this method as least expensive, least time consuming and most convenient. For collecting data, 445 respondents were contacted. Among them, 360 people gave responses. But, 42 responses were discarded as they were unusable due to incomplete responses. Thus, the remaining 318 responses were included in this study.

\subsection{Pretesting}

For pretesting, the questionnaire was tested with twenty two respondents who participated voluntarily. The results obtained from the questionnaire were modified based on the difficulties observed at the time of pilot study. Finally, 22 items were retained that had best fit with the study.

\subsection{Data Collection}

Data was collected from the three most populated cities in Bangladesh (Dhaka, Chattogram and Khulna). Dhaka is the capital city of Bangladesh. Besides, Chattogram and 
Khulna are renowned cities for commercial activities. People from every region are available in these cities. It facilitates to meet with wide range of people of different classes and occupations. These regions facilitate collection and authentication of data that are necessary for this study. For these reasons, respondents were chosen from these regions. Prior to data collection, interviewers were trained and instructed on how to administrate the survey instrument and to include respondents with different demographic profile. The data collection was conducted over a three week period on both weekdays and weekend. All items were measured using five point Likert scale previously used by Park et al. (2007) in this area with 1 representing "strongly disagree" and 5 representing "strongly agree".

\subsection{Measures}

To ensure content validity of the scales, all items selected for the constructs are adapted from the previous literature and modified to fit to represent imitation jewelry purchase intention in the context of Bangladesh. In addition, discussion with academicians and researchers, earlier literature review and personal experience helped in designing the items selected in the study. In our study, we adopted three constructs from TPB model developed by Ajzen (1991) and behavioral intention was adopted from Taylor \& Todd (1995). All items of attitude, PBC and behavioral intention were adopted from Taylor \& Todd (1995). And all items of SN were drawn from Venkatesh (2000). Furthermore, the remaining constructs namely FI (Park et al., 2007; Zhang \& Kim, 2013), VC (Riquelme et al., 2012) and PK (O'Cass, 2004) were adopted to conduct the study. All items of FI were drawn from Park et al. (2007) and items of VC were adopted from Lichtenstein, Netemeyer, \& Burton (1990) and all items of PK were adopted from O'Cass (2004).

\subsection{Data Analysis Methods}

The data were analyzed using Statistical Package for Social Science (SPSS) and Analysis of Moment Structures (AMOS). At first, exploratory factor analysis (EFA) and reliability analysis were done through SPSS 20. Furthermore, Structural Equation Model was conducted using AMOS 23. In this research, AMOS was used for testing confirmatory factor analysis (CFA) and the structural model.

\section{DATA ANALYSIS AND RESULTS}

The demographic profiles of the respondents are tabulated in the Table 1. The total number of the respondents were 318. The majority of the respondents were unmarried women (54\%). Most of the respondents were in the age range of 31-50 years old (61\%). The rest of 
the participants were in the range of 15-30 years old (39\%). More than half of the respondents were university graduates (59\%). The rest of respondents were university post graduates $(33 \%)$ and HSC degree holders (8\%). The majority of respondents were housewife (38\%). The rest of them were job holders (30\%) and students (32\%).

Table 1.Respondents' Personal Features

\begin{tabular}{|c|c|c|c|c|c|c|c|}
\hline Description & Category & Frequency & Percentage & Description & Category & Frequency & Percentage \\
\hline Marital Status & $\begin{array}{l}\text { Unmarried } \\
\text { Married }\end{array}$ & $\begin{array}{l}173 \\
145\end{array}$ & $\begin{array}{l}54 \\
46\end{array}$ & Level of education & $\begin{array}{c}\text { HSC } \\
\text { Graduate } \\
\text { Post Graduate }\end{array}$ & $\begin{array}{c}25 \\
189 \\
104\end{array}$ & $\begin{array}{c}8 \\
59 \\
33\end{array}$ \\
\hline Age & $\begin{array}{l}15-30 \\
31-50\end{array}$ & $\begin{array}{l}123 \\
195\end{array}$ & $\begin{array}{l}39 \\
61\end{array}$ & Occupation & $\begin{array}{c}\text { Job Holder } \\
\text { Student } \\
\text { Housewife }\end{array}$ & $\begin{array}{c}96 \\
101 \\
121\end{array}$ & $\begin{array}{l}30 \\
32 \\
38\end{array}$ \\
\hline
\end{tabular}

\subsection{Exploratory Factor Analysis (EFA)}

Exploratory factor analysis (EFA) with Varimax Rotation was done for the dependent and independent variables which shows that extracted variables contribute more than 50 percent of the total variance.

Table 2.EFA Loadings And Reliability Of Scales

\begin{tabular}{|c|c|c|c|c|c|c|c|}
\hline Component Name & Items & Loadings & Cronbach'sAlpha & Component Name & Items & Loadings & Cronbach'sAlpha \\
\hline Attitude (ATT) & $\begin{array}{l}\text { ATT1 } \\
\text { ATT2 } \\
\text { ATT3 } \\
\text { ATT4 }\end{array}$ & $\begin{array}{l}.768 \\
.829 \\
.831 \\
.782\end{array}$ & .837 & $\begin{array}{l}\text { Perceived } \\
\text { Behavioral Control } \\
\text { (PBC) }\end{array}$ & $\begin{array}{l}\mathrm{PBC} 1 \\
\mathrm{PBC} 2 \\
\mathrm{PBC} 3\end{array}$ & $\begin{array}{l}.879 \\
.900 \\
.878\end{array}$ & .873 \\
\hline $\begin{array}{l}\text { Fashion } \\
\text { Innovativeness } \\
\text { (FI) }\end{array}$ & $\begin{array}{l}\text { FI1 } \\
\text { FI2 } \\
\text { FI3 }\end{array}$ & $\begin{array}{l}.860 \\
.889 \\
.891 \\
\end{array}$ & .867 & $\begin{array}{l}\text { Product } \\
\text { Knowledge (PK) }\end{array}$ & $\begin{array}{l}\text { PK1 } \\
\text { PK2 } \\
\text { PK3 }\end{array}$ & $\begin{array}{l}.862 \\
.811 \\
.893 \\
\end{array}$ & .831 \\
\hline $\begin{array}{l}\text { Value } \\
\text { Consciousness } \\
\text { (VC) }\end{array}$ & $\begin{array}{l}\text { VC1 } \\
\text { VC2 } \\
\text { VC3 } \\
\end{array}$ & $\begin{array}{l}.841 \\
.866 \\
.854 \\
\end{array}$ & .851 & $\begin{array}{l}\text { Consumer } \\
\text { Behavioral } \\
\text { Intention }(\mathrm{CBI}) \\
\end{array}$ & $\begin{array}{l}\mathrm{CBI} 1 \\
\mathrm{CBI} 2 \\
\mathrm{CBI} 3 \\
\end{array}$ & $\begin{array}{l}.846 \\
.895 \\
.888 \\
\end{array}$ & .879 \\
\hline Social Norm (SN) & $\begin{array}{l}\text { SN1 } \\
\text { SN2 } \\
\text { SN3 } \\
\end{array}$ & $\begin{array}{l}.865 \\
.864 \\
.847 \\
\end{array}$ & .850 & & & & \\
\hline
\end{tabular}

All the items in the Table 2 have loadings greater than .70 and factors loading above .70 are accepted as it shows a significant correlation among the variables (Hair, Black, Babin, Anderson, \& Tatham, 2010). Furthermore, the KMO index is 0.756 which is greater than 0.5 (Kaiser, 1974) indicating that sample size is adequate for the study and the Sig. of Bartlett's test is $0.000<0.05$. Moreover, the value of Cronbach's Alpha for all variables are greater than .75 while Hinton Brownlow, McMurray, \& Cozens (2004) suggested that an Alpha score greater than .75 indicates a highly reliable scale. So, the results shows all variables are statistically well related and reliable.

\subsection{Measurement Model: Assessing Reliability And Validity}


Any measurement model aims at illustrating how observed variables serve as measurement instruments for the unobserved or latent variables (Amin, Uthamaputhran, \& Ali, 2015). The following Table 3 illustrates the factor loadings for all items, and it shows that all the factor loadings are above the cut off value .70 which ensures convergent validity as recommended by Chin, Gopal, \& Salisbury (1997) and Hair et al. (2010). Generally, the CR values and AVE values are regarded as the key assessment to determine the convergent validity. As shown in Table 3, all the constructs yield the CR values greater than .70 and to determine the internal consistency of the variables the cut-off value must be greater than .70 (Nunnally, 1978). Similarly, all the values of AVE are greater than .50, which also determines the good convergent validity of all constructs (Fornell \& Larcker, 1981) in the study. Moreover, the results of the CFA of 22 items showed a well-accepted goodness-of-fit for the study, where Chi-Square is significant $\left(\mathrm{x}^{2}=248.664, \mathrm{x}^{2} /\right.$ degree of freedom is 1.366). Besides, Root Mean Square Error of Approximation (RMSEA) value is .034 and Comparative Fit Index (CFI) value is .980 .

Table 3.Validity And Reliability For The Constructs

\begin{tabular}{|c|c|c|c|c|c|c|c|c|c|}
\hline Constructs & Items & Item loadings & AVE & $\mathrm{CR}$ & Constructs & Items & Item loadings & AVE & $\mathrm{CR}$ \\
\hline Attitude (ATT) & $\begin{array}{l}\text { ATT1 } \\
\text { ATT2 } \\
\text { ATT3 } \\
\text { ATT4 } \\
\end{array}$ & $\begin{array}{l}.71 \\
.77 \\
.79 \\
.75 \\
\end{array}$ & 0.570 & 0.841 & $\begin{array}{l}\text { Perceived } \\
\text { Behavioral Control } \\
\text { (PBC) }\end{array}$ & $\begin{array}{l}\text { PBC1 } \\
\text { PBC2 } \\
\text { PBC3 }\end{array}$ & $\begin{array}{l}.84 \\
.86 \\
.81\end{array}$ & 0.698 & 0.874 \\
\hline $\begin{array}{l}\text { Fashion } \\
\text { Innovativeness (FI) }\end{array}$ & $\begin{array}{l}\text { FI1 } \\
\text { FI2 } \\
\text { FI3 } \\
\end{array}$ & $\begin{array}{l}.76 \\
.87 \\
.86 \\
\end{array}$ & 0.691 & 0.870 & $\begin{array}{l}\text { Product Knowledge } \\
(\mathrm{PK})\end{array}$ & $\begin{array}{l}\text { PK1 } \\
\text { PK2 } \\
\text { PK3 }\end{array}$ & $\begin{array}{l}.76 \\
.71 \\
.90 \\
\end{array}$ & 0.633 & 0.837 \\
\hline $\begin{array}{l}\text { Value } \\
\text { Consciousness } \\
\text { (VC) }\end{array}$ & $\begin{array}{l}\mathrm{VC} 1 \\
\mathrm{VC} 2 \\
\mathrm{VC} 3 \\
\end{array}$ & $\begin{array}{l}.77 \\
.90 \\
.77 \\
\end{array}$ & 0.661 & 0.853 & $\begin{array}{l}\text { Consumer } \\
\text { Behavioral } \\
\text { Intention (CBI) }\end{array}$ & $\begin{array}{l}\text { CBI1 } \\
\text { CBI2 } \\
\text { CBI3 }\end{array}$ & $\begin{array}{l}.78 \\
.83 \\
.92 \\
\end{array}$ & 0.713 & 0.881 \\
\hline Social Norm (SN) & $\begin{array}{l}\text { SN1 } \\
\text { SN2 } \\
\text { SN3 }\end{array}$ & $\begin{array}{l}.82 \\
.85 \\
.77 \\
\end{array}$ & 0.659 & 0.853 & & & & & \\
\hline
\end{tabular}

Furthermore, the following table illustrates the discriminant validity of the study. As all the diagonal values are less than .85 , it ensures discriminant validity (Fornell \& Larcker, 1981) of the study.

Table 4.Discriminant Validity

\begin{tabular}{|l|l|l|l|l|l|l|l|}
\hline & PK & FI & VC & ATT & SN & PBC & CBI \\
\hline PK & $\mathbf{0 . 7 9 6}$ & & & & & & \\
\hline FI & 0.082 & $\mathbf{0 . 8 3 1}$ & & & & & \\
\hline VC & 0.202 & 0.030 & $\mathbf{0 . 8 1 3}$ & & & & \\
\hline ATT & 0.181 & 0.163 & 0.375 & $\mathbf{0 . 7 5 5}$ & & & \\
\hline SN & 0.136 & 0.195 & 0.257 & 0.294 & $\mathbf{0 . 8 1 2}$ & & \\
\hline PBC & -0.008 & 0.047 & 0.188 & 0.038 & 0.111 & $\mathbf{0 . 8 3 5}$ & \\
\hline CBI & 0.217 & 0.260 & 0.170 & 0.270 & 0.218 & 0.172 & $\mathbf{0 . 8 4 5}$ \\
\hline
\end{tabular}

So, the overall results of the study indicate a well-accepted reliability and validity of all constructs in the study. 


\subsection{Structural Model}

To illustrate the factors affecting consumer purchase intention towards imitation jewelry, a structural model was employed. The results of the model (Table 5) showed that Chi-Square is significant $\left(\mathrm{x}^{2}=252.102, \mathrm{x}^{2} /\right.$ degree of freedom $\left.=1.355, \mathrm{P}=.001<.05\right)$. Besides, Root Mean Square Error of Approximation (RMSEA) value is .033 and Comparative Fit Index (CFI) value is .980. Furthermore, the rest of model fit results are: GFI $=.934$, AGFI $=.911, \mathrm{PGFI}=.687, \mathrm{NFI}=.930, \mathrm{RFI}=.913, \mathrm{IFI}=.981, \mathrm{PNFI}=.749$, and PCFI $=.789$. The overall results of goodness-of-fit indices (Table 5) showed that the model met all criteria.

Table 5.Goodness Of Fit Statistics

\begin{tabular}{|l|l|l|l|l|l|}
\hline \multicolumn{1}{|c|}{ Fit Indices } & \multicolumn{1}{c|}{ Criteria } & Indicators & \multicolumn{1}{c|}{ Fit Indices } & criteria & Indicators \\
\hline Chi- square & & 252.102 & Comparative fit index (CFI) & $>0.9$ & .980 \\
\hline Chi- square/(degree of freedom) & $<5$ acceptable; $<3$ good & 1.355 & Normed fit index (NFI) & $>0.9$ & .930 \\
\hline $\begin{array}{l}\text { Adjusted goodness of fit index } \\
\text { (AGFI) }\end{array}$ & $>0.8$ acceptable; $>0.9$ good & .911 & Relative fit index (RFI) & $>0.9$ & .913 \\
\hline
\end{tabular}

Table 6 represents the result of hypothesis where attitude $(\beta=.200, \mathrm{p}=.007<.05)$, SN $(\beta=.124, \mathrm{p}=.032<.05)$ and $\operatorname{PBC}(\beta=.177, \mathrm{p}=.010<.05)$ have significant influence on intention to purchase imitation jewelry that means TPB has significant effect on intention to purchase imitation jewelry. This result has correspondence with SelvanPerumal \& Sapihan (2017) and Kim \& Karpova (2010). Hence, H1, H2 and H3 are supported. Likewise, PK ( $\beta=$ $.183, \mathrm{p}=.004<.05)$ also positively and significantly influence behavioral intention of consumers. Thus, $\mathrm{H} 4$ is supported.

Table 6.The Results Of The Structural Model

\begin{tabular}{|l|c|c|c|c|}
\hline Hypothesis & Standardized Beta & S.E. & P Value & C.R. \\
\hline H1: ATT $\rightarrow$ CBI & .200 & .074 & .007 & 2.688 \\
\hline H2: SN $\rightarrow$ CBI & .124 & .058 & .032 & Decision \\
\hline H3: PBC $\rightarrow$ CBI & .177 & .069 & .010 & 2.144 \\
\hline H4: PK $\rightarrow$ CBI & .183 & .064 & .004 & 2.564 \\
\hline H5: FI $\rightarrow$ ATT & .155 & .056 & .005 & 2.878 \\
\hline H6: VC $\rightarrow$ ATT & .377 & .069 & .000 & Supported \\
\hline
\end{tabular}

Furthermore, FI $(\beta=.155, \mathrm{p}=.005<.05)$ and VC $(\beta=.377, \mathrm{p}=.000<.001)$ influence attitude towards imitation jewelry. And this findings are theoretically similar with the findings of Riquelme et al., (2012); Toklu \& Baran (2017). So, H5 and H6 are supported.

\section{DISCUSSION}

The results of this study provide empirical evidence and knowledge about consumer purchase intention towards imitation jewelry. Starting from the first hypothesis, what clearly emerged as the fact that consumer who intends to purchase imitation jewelry believe that they 
get more pleasure, positive impression as well as they have curiosity about knowing people using imitation jewelry. And these considerations form a positive attitude towards imitation jewelry. Moreover, Kim \& Karpova (2010) stated that intention towards imitated products is substantial and attitude forms this substantiality. However, very often, attitude alone is not enough to explain consumer behavior.

Hence, according to second hypothesis of the study: $\mathrm{SN}(\beta=.124, p<0.05)$ have positive and significant influence on behavioral intention. This variable is decisive in many circumstances including the context of imitation jewelry as highlighted by the study. As individual values relationship, gives more emphasis on others opinions in uncertain or ambiguous situation (Penz\& Stottinger, 2005), this tends to place a behavior to purchase imitation jewelry. According to the analysis, $\operatorname{PBC}(\beta=.177, p<0.05)$ also plays a decisive role in shaping the behavioral intention of consumers in purchasing imitation jewelry. The findings indicate that using imitation jewelry is within the control of the consumer and they have enough knowledge and resources in purchasing and using the best jewelry for them. This finding was in line with Penz \& Stottinger (2005) who found that the more people think they are able to engage in that behavior and have the required resources such as time and money, the more they are willing to purchase imitated products. So, in case of purchasing or using imitation jewelry, Bangladeshi consumer perceive that they have more behavioral control. Another variable apparently capable of positively influencing the behavioral intention of consumer towards purchasing imitation jewelry is $\mathrm{PK}(\beta=.183, p<0.05)$. Findings of the study denoted that consumers who have more experience, familiarity and expertise in choosing jewelry, have more intention in purchasing imitation jewelry. In support of this findings, O'Cass (2004) stated that PK regarding fashion products can come from consumption related experience, advertising, or interactions with salesperson and information from friends or other associates. Likewise, O'Cass (2004) found PK and fashion involvement is significantly related. So, consumers with high knowledge about jewelry are more intended to purchase imitation jewelry.

Finally, our study stated that FI $(\beta=.155, p<0.05)$ and VC $(\beta=.377, p<0.05)$ positively and significantly influence consumers' attitudes towards purchasing imitation jewelry. In this regard, Jordaan \& Simpson (2006) as well as Workman \& Caldwell (2007) stated earlier in their studies that fashion innovators prefer shopping more and they are more willing to purchase new fashion goods. Besides, our study indicated that value conscious consumer shows more favorable attitude towards imitation jewelry because they get more 
benefit than cost. Furthermore, value conscious consumers don't sacrifice value for low price. For this reason, consumers of imitation jewelry don't want to give up quality. In light of what has been discussed so far in this research, it is possible to believe that the findings contribute theoretically as well as practically, as discussed in the following section.

\section{IMPLICATIONS}

\subsection{Theoretical Contribution}

The results emerged from the analysis led us to consider the work as a potentially useful for both scholars and practitioners. First, the study can be useful for all those researchers who study people's behavior and more importantly consumer behavior, as it contributes to the enrichment of literature related to the factors influencing consumer intention. Specially, all hypotheses originally formulated appeared as satisfied and highlighting that the ability of the factors taken into consideration have a significant impact on consumer behavioral intention in purchasing imitation jewelry. Precisely, the analysis confirmed that attitude, SN and PBC have significant impact on behavioral intention regarding imitation jewelry. So, theory of planned behavior developed by Ajzen (1991) successfully predict consumer intention in purchasing imitation jewelry. However, in addition, the proposed model was an extension of the TPB model with inclusion of three additional factors namely, PK, VC and FI, thus formulating the Extended Theory of Planned Behavior (ETPB). PK was able to influence the behavioral intention of consumer and VC as well as FI were able to influence consumer attitude towards purchasing imitation jewelry. In fact, the ETPB represents a possible theoretical development as the factors are able to influence consumer behavioral intention as well as attitude in jewelry sector. So, this model may work as a formation of other conceptual models and can change the perspective in scientific research regarding consumer intention.

\subsection{Managerial Insights}

The proposed model of this study can provide some managerial insights. It offers some empirical evidence that the factors used in this research are capable of clearly impacting on consumer behavioral intention and predicting future purchase intention of imitation jewelry. Concretely, this work can be considered as instrumental in maximizing the success of business of imitation jewelry in Bangladesh. In fact, this observation will help those managers and entrepreneurs who want to understand consumer behavior and the reasons behind purchasing jewelry, especially in the context of imitation jewelry. Understanding the reasons 
behind consumer's positive behavioral intention regarding imitation jewelry allows the businessmen in predicting future trends, ensuring the availability of more time in defining and finally implementing them to attract and satisfy customers' needs. As suggested by the results of the analysis, much attention should be given on various factors including attitude. It is necessary to stimulate the mental state of consumer and make it believable that using imitation jewelry gives them economic and social benefits. Furthermore, strategies aimed at stimulating purchase intention for imitation jewelry, cannot ignore SN. They have to take considerations of the direct and indirect effect from other people (relatives, friends, colleagues etc.) that each individual deals with regarding the purchase of imitation jewelry. Because consumer intention and choice in purchasing fashion products, especially imitation jewelry, is widely influenced by their associates. Another variable that marketers should pay attention is $\mathrm{PBC}$, as it is capable of influencing an individual's behavioral intention. Actually, individuals tend to purchase when they think they can control required resources and time for the purchase. So it might be advantageous in making people to think that they have all resources needed to purchase imitation jewelry. In the same way, PK can be helpful for creating positive intention towards purchasing imitation jewelry. If it is possible to create awareness about the functionality and benefits of using imitation jewelry, acceptance of imitation jewelry may increase. Beside this, in influencing positive attitude towards imitation jewelry purchase, marketers should be aware of the value that customers want, as the results show imitation jewelry purchasers are more value conscious. Finally, the results indicate that FI is strong enough in developing positive attitude towards imitation jewelry purchase. So, marketers in jewelry industry, especially in imitation jewelry should uphold innovativeness in their products as well as in promotional activities.

\section{LIMITATIONS AND FUTURE RESEARCH DIRECTIONS}

Despite the implications of the study, there are also some limitations which might restrict the application and generalization of the findings of the study. This study was conducted using the responses of the sample population from three major cities namely Dhaka, Chattogram and Khulna. Hence, the result may not provide a true reflection of the intention to purchase imitation jewelry because approximately $76 \%$ of the population of Bangladesh lives in rural areas that have different socioeconomic condition and privileges including infrastructure, education and access to information. Beside these, the sample size could be increased. In the context of Bangladesh, the model proposed in this study can also be applied to predict the purchase intention for other types of fashion goods such as clothing, 
bags and shoes. For generalizations of our findings, further research needs to be conducted considering other culture, rural areas, different socioeconomic groups and groups with different religious beliefs.

\section{CONCLUSION}

The use of imitation jewelry has become a popular issue in all over the world. Due to urbanization and easy access to media, people are more aware and more fashionable. Owing to this, consumption of fashion products, especially imitation jewelry, is increasing. Hence, our main objective was to investigate the factors affecting consumer purchase intention towards imitation jewelry in Bangladesh. We applied Ajzen's theory of planned behavior (Attitude, SN and PBC) along with some other variables (PK, VC and FI) and proposed ETBP model that can predict consumer purchase intention towards imitation jewelry in Bangladesh. And all proposed variables were significant in predicting consumer intention towards imitation jewelry. The results revealed that Bangladeshi consumers give more value on social relationship and preferences of others in purchasing imitation jewelry. Beside this, economic and social benefits are more valuable because the consumers are value conscious. However, this study can act as an incentive for practitioners who deal in imitation jewelry; and business success in this industry is achievable through thoughtful inclusion of the identified factors. 
APPENDIX A: LIST OF MEASURES

\begin{tabular}{|c|c|c|c|}
\hline Constructs & Items & Statement & Sources \\
\hline \multirow{4}{*}{ Attitude } & ATT1 & Purchasing imitation jewelry is a good idea. & \multirow{4}{*}{$\begin{array}{l}\text { Ajzen (1991); } \\
\text { Taylor \& Todd (1995) }\end{array}$} \\
\hline & ATT2 & I like knowing about people who use imitation jewelry. & \\
\hline & ATT3 & I believe using imitation jewelry would be pleasant. & \\
\hline & ATT4 & I have a positive impression toward using imitation jewelry. & \\
\hline \multirow{3}{*}{$\begin{array}{l}\text { Fashion } \\
\text { Innovativeness }\end{array}$} & FI1 & Compared to my friends, I own few new imitation jewelry. & \multirow{3}{*}{$\begin{array}{l}\text { Park et al., (2007); } \\
\text { Zhang \& Kim (2013) }\end{array}$} \\
\hline & FI2 & $\begin{array}{l}\text { If I heard that a new fashion or imitation jewelry was available in the store, I would be } \\
\text { interested enough to buy it. }\end{array}$ & \\
\hline & FI3 & I will buy a new imitation jewelry even if I have not seen it before. & \\
\hline \multirow{3}{*}{$\begin{array}{l}\text { Value } \\
\text { Consciousness }\end{array}$} & VC1 & I'm very concerned about low prices, but I am equally concerned about product quality. & \multirow{3}{*}{$\begin{array}{l}\text { Lichtenstein, } \\
\text { Netemeyer, \& Burton } \\
\text { (1990); } \\
\text { Riquelme et al. (2012) }\end{array}$} \\
\hline & VC2 & $\begin{array}{l}\text { When I shop, I usually compare the price information for brands "I normally buy" } \\
\text { requirements before I buy them. }\end{array}$ & \\
\hline & VC3 & I always check prices at the market to be sure I get the best value for the money I spend. & \\
\hline \multirow{3}{*}{$\begin{array}{l}\text { Subjective } \\
\text { Norms }\end{array}$} & SN1 & People who influence my behavior think it is preferable to use imitation jewelry. & \multirow{3}{*}{$\begin{array}{l}\text { Ajzen (1991); } \\
\text { Venkatesh (2000) }\end{array}$} \\
\hline & SN2 & $\begin{array}{l}\text { People important to me think it is preferable not to spend too much money for diamond or } \\
\text { gold jewelry. }\end{array}$ & \\
\hline & SN3 & In general, people support me in using imitation jewelry. & \\
\hline \multirow{3}{*}{$\begin{array}{l}\text { Perceived } \\
\text { Behavioral } \\
\text { control }\end{array}$} & PBC1 & I would be able to use imitation jewelry when it is required. & \multirow{3}{*}{$\begin{array}{l}\text { Ajzen (1991); } \\
\text { Taylor \& Todd (1995) }\end{array}$} \\
\hline & PBC2 & Using imitation jewelry in entirely within my control. & \\
\hline & PBC3 & $\begin{array}{l}\text { I have the resources and knowledge and ability in purchasing the best imitation jewelry for } \\
\text { me. }\end{array}$ & \\
\hline \multirow{3}{*}{$\begin{array}{l}\text { Product } \\
\text { Knowledge }\end{array}$} & PK1 & I am very familiar with fashion jewelry or imitation jewelry. & \multirow[t]{3}{*}{ O’Cass (2004) } \\
\hline & PK2 & I am an experienced user of imitation jewelry. & \\
\hline & PK3 & I would classify myself as an expert on imitation jewelry. & \\
\hline \multirow{3}{*}{$\begin{array}{l}\text { Consumer } \\
\text { Behavioral } \\
\text { Intention }\end{array}$} & CBI1 & I intend to purchase imitation jewelry very frequently. & \multirow[t]{3}{*}{ Taylor \& Todd (1995) } \\
\hline & $\mathrm{CBI} 2$ & I intend to use imitation jewelry in different occasions. & \\
\hline & CBI3 & I recommend others to use imitation jewelry. & \\
\hline
\end{tabular}




\section{REFERENCES}

Ajzen, I. (1985). From Intentions to Actions: A Theory of Planned Behavior. In Action Control (pp. 11-39). Berlin, Heidelberg: Springer Berlin Heidelberg.

Ajzen, I. (1991). The theory of planned behavior. Organizational Behavior and Human Decision Processes, 50(2), 179-211.

Allport, G. W. (1967). Attitudes in Attitude Theory and Measurement. New York, NY, USA: John Willey Sons.

Amin, M., Uthamaputhran, S., \& Ali, F. (2015). The effectiveness of green product positioning and marketing strategies towards purchase intention in Malaysia. International Journal of Innovation and Learning , $17(4), 516-528$.

Ang, H. S., Cheng, P. S., Lim, E. A. C., \& Tambyah, S. K. (2001). Spot the difference: consumer responses towards counterfeits. Journal of Consumer Marketing, 18(3), 219-235.

Baker, W. E., Gahtani, A. S. S., \& Hubona, G. S. (2007). The effects of gender and age on new technology implementation in a developing country. Information Technology \& People, 20(4), 352-375.

Bandura, A., Adams, N. E., \& Beyer, J. (1977). Cognitive processes mediating behavioral change. Journal of Personality and Social Psychology, 35(3), 125-139.

Bandura, A., Adams, N. E., Hardy, A. B., \& Howells, G. N. (1980). Tests of the generality of self-efficacy theory. Cognitive Therapy and Research, 4(1), 39-66.

Bartleby. (2009). Artificial / Imitation Jewelry Sourcing \& Market Feasibility Report. |Retrieved from https://www.bartleby.com/essay/Artificial-Imitation-Jewelry-Sourcing-Market-Feasibility-ReportPKSEWE9KRZYS

Beaudoin, P., \& Lachance, M. J. (2006). Determinants of Adolescents' Brand Sensitivity to Clothing. Family and Consumer Sciences Research Journal, 34(4), 312-331.

Beaudoin, Pierre, Moore, M. A., \& Goldsmith, R. E. (2000). Fashion Leaders' and Followers' Attitudes Toward Buying Domestic and Imported Apparel. Clothing and Textiles Research Journal, 18(1), 56-64.

Bian, X., \& Moutinho, L. (2009). An investigation of determinants of counterfeit purchase consideration. Journal of Business Research, 62(3), 368-378.

Bloch, P. H., Bush, R. F., \& Campbell, L. (1993). Consumer "accomplices" in product counterfeiting: a demand side investigation. Journal of Consumer Marketing, 10(4), 27-36.

Campbell, D. T. (1947). The generality of a social attitude. University of California, Berkeley.

Chang, M. K. (1998). Predicting Unethical Behavior: A Comparison of the Theory of Reasoned Action and the Theory of Planned Behavior. Journal of Business Ethics, 17(16), 1825-1834.

Cheng, S., Lam, T., \& Hsu, C. H. C. (2006). Negative Word-of-Mouth Communication Intention: An Application of the Theory of Planned Behavior. Journal of Hospitality \& Tourism Research, 30(1), 95116.

Chin, W. W., Gopal, A., \& Salisbury, W. D. (1997). Advancing the Theory of Adaptive Structuration: The Development of a Scale to Measure Faithfulness of Appropriation. Information Systems Research, 8(4), $342-367$.

Conner, M., \& Abraham, C. (2001). Conscientiousness and the Theory of Planned Behavior: Toward a more Complete Model of the Antecedents of Intentions and Behavior. Personality and Social Psychology 
Bulletin, 27(11), 1547-1561.

Eagly, A. H., \& Chaiken, S. (1993). The psychology of attitudes. Orlando, FL, US: Harcourt Brace Jovanovich College Publishers.

East, R. (2000). Complaining as planned behavior. Psychology and Marketing, 17(12), 1077-1095.

Efrat, K., \& Shoham, A. (2013). The theory of planned behavior, materialism, and aggressive driving. Accident Analysis \& Prevention, 59, 459-465.

Fishbein, M. (1967). Readings in attitude theory and measurement. New York: John Wiley \& Sons.

Fornell, C., \& Larcker, D. F. (1981). Evaluating Structural Equation Models with Unobservable Variables and Measurement Error. Journal of Marketing Research, 18(1), 39-50.

Grossman, G. M., \& Shapiro, C. (1988). Foreign Counterfeiting of Status Goods. The Quarterly Journal of Economics, 103(1), 79.

Hair, J. F., Black, W. C., Babin, B. J., Anderson, R. E., \& Tatham, R. L. (2010). Multivariate data Analysis (7th Ed.). Prentice-Hall, Upper Saddle River, NJ.

Hinton, P. R., Brownlow, C., McMurray, I., \& Cozens, B. (2004). SPSS Explained.Tourism Planning \& Development. London and New York: Taylor and Francis Group.

Jain, S., Khan, M. N., \& Mishra, S. (2017). Understanding consumer behavior regarding luxury fashion goods in India based on the theory of planned behavior. Journal of Asia Business Studies, 11(1), 4-21.

Jewellery sector in jeopardy as artisans opt out (2017, December 1). Financial Express.

Johnson, E. J., \& Russo, J. E. (1984). Product Familiarity and Learning New Information. Journal of Consumer Research, 11(1), 542.

Jordaan, Y., \& Simpson, M. N. (2006). Consumer innovativeness among females in specific fashion stores in the Menlyn shopping centre. Journal of Family Ecology and Consumer Sciences, 14, 32-40.

Joseph, H. (2016). A Study on the Effect of Imitation Jewellery on Real Sales of Gold Jewellery. IJEMR, 6(07).

Kaiser, H. F. (1974). An index of factorial simplicity. Psychometrika, 39(1), 31-36.

Kim, H., \& Karpova, E. (2010). Consumer Attitudes Toward Fashion Counterfeits: Application of the Theory of Planned Behavior. Clothing and Textiles Research Journal, 28(2), 79-94.

Kim, Y., \& Han, H. (2010). Intention to pay conventional-hotel prices at a green hotel - a modification of the theory of planned behavior. Journal of Sustainable Tourism, 18(8), 997-1014.

Krijger, M. (2015). CBI Product Factsheet: Costume Jewellery in ltaly. Retrieved from https ://www.c bi.eu/sites/default/files/market_information/researches/product-factsheet-italy-costume-jewellery-20 15.pdf

Krishnan, A., \& Nandhini, D. M. (2017). A study on the factors which leading customers to purchase gold jewellery with special reference to working women. International Journal of Mechanical Engineering and Technology (IJMET), 8(12), 1020-1029.

Kwong, T. C. H., \& Lee, M. K. O. (2002). Behavioral intention model for the exchange mode Internet music piracy. In Proceedings of the 35th Annual Hawaii International Conference on System Sciences (pp. 24812490). Big Island, HI, USA: IEEE Comput. Soc.

Laroche, M., Bergeron, J., \& Barbaro-Forleo, G. (2001). Targeting consumers who are willing to pay more for 
environmentally friendly products. Journal of Consumer Marketing, 18(6), 503-520.

Lastovicka, J. L. (1979). Questioning the Concept of Involvement Defined Product Classes. ACR North American Advances, 06, 174-179.

Lichtenstein, D. R., Netemeyer, R. G., \& Burton, S. (1990). Distinguishing Coupon Proneness from VC: An Acquisition-Transaction Utility Theory Perspective. Journal of Marketing, 54(3), 54-67.

MarketWatch. (2019). Imitation Jewellery Market 2019 Global Industry Size, Share, Demand, Top Manufacturers, Industry Size, Future Growth by 2023: Industry Research Co. Retrieved from https://www.marketwatch.com/press-release/imitation-jewellery-market-2019-global-industry-size-sharedemand-top-manufacturers-industry-size-future-growth-by-2023-industry-research-co-2019-07-26

Nunnally, J. C. (1978). Psychometric Theory. Psychological Bulletin (2nd ed.). New York: McGraw-Hill.

O’Cass, A. (2004). Fashion clothing consumption: antecedents and consequences of fashion clothing involvement. European Journal of Marketing, 38(7), 869-882.

Önder, Y., \& Yeşilyurt, F. (2012). A study on modern jewelry designed with traditional Turkish ceramics and women's acceptance of this jewelry. Atatürk Üniversitesi Sosyal Bilimler Enstitüsü Dergisi, 16(2), 271287.

Orendorff, A. (2019). The Ecommerce Fashion Industry: Statistics, Trends \&amp; Strategy. Retrieved from https://www.shopify.com/enterprise/ecommerce-fashion-industry

Pan, A. (2008). China Gem and Jewelry Market Overview: Selling Jewelry in China - Albert Pan - Google Books.

Park, H., Burns, D. L., \& Rabolt, N. J. (2007). FI, materialism, and attitude toward purchasing foreign fashion goods online across national borders. Journal of Fashion Marketing and Management: An International Journal, 11(2), 201-214.

Park, H. S. (2000). Relationships among attitudes and SN: Testing the theory of reasoned action across cultures. Communication Studies, 51(2), 162-175.

Peace, A. G., Galletta, D. F., \& Thong, J. Y. L. (2003). Software Piracy in the Workplace: A Model and Empirical Test. Journal of Management Information Systems, 20(1), 153-177.

Penz, E., \& Stottinger, B. (2005). Forget the Areal@ Thingbtake the Copy! an Explanatory Model For the Volitional Purchase of Counterfeit Products. Advances in Consumer Research, 32, 568-575.

Phau, I., \& Teah, M. (2009). Devil wears (counterfeit) Prada: a study of antecedents and outcomes of attitudes towards counterfeits of luxury brands. Journal of Consumer Marketing, 26(1), 15-27.

Raju, P. S., \& Reilly, M. D. (1980). Product familiarity and information processing strategies: An exploratory investigation. Journal of Business Research, 8(2), 187-212.

Research and Markets. (2018). Global Imitation Jewelry Market 2019-2023. Retrieved from htt ps://www .researchandmarkets.com/reports/4721345/global-imitation-jewelry-market-2019-2023

Riquelme, H. E., Abbas, E. M. S., \& Rios, R. E. (2012). Intention to purchase fake products in an Islamic country. Education, Business and Society: Contemporary Middle Eastern Issues, 5(1), 6-22.

Rogers, M. E. (1983). Diffusion of Innovations (3rd ed.). The Free Press.

Sabbir, M. M., Hossain, M. I., \& Nomi, M. (2017). Analysis of Women's Preference of lmitation Jewelry: Bangladesh Perspective Abstract. Journal of Business, Society and Science, 5, 44-53. 
Schepers, J., \& Wetzels, M. (2007). A meta-analysis of the technology acceptance model: Investigating SN and moderation effects. Information \& Management, 44(1), 90-103.

SelvanPerumal, \& Sapihan, A. R. (2017). Analysing Purchasing Intention of Counterfeit Sportswear Products in Klang Valley, Malaysia. IOSR Journal of Business and Management (IOSR-JBM), 19(1), 77-81.

Sultana, M., Siddique, J. P., \& Islam, S. (2015). Analysis of Consumer Behaviour in Jewellery Business: An Empirical Study on Bangladesh. European Journal of Business and Management, 7(5), 79-84.

Taylor, S., \& Todd, P. (1995). Assessing IT Usage: The Role of Prior Experience. MIS Quarterly, 19(4), 561.

Toklu, I. T., \& Baran, S. (2017). Attitude towards Counterfeit of Luxury Brands: A Research on Consumers in Turkey. International Journal of Academic Research in Business and Social Sciences, 7(11), 618-632.

Tom, G., Garibaldi, B., Zeng, Y., \& Pilcher, J. (1998). Consumer demand for counterfeit goods. Psychology and Marketing, 15(5), 405-421.

Tommasetti, A., Singer, P., Troisi, O., \& Maione, G. (2018). Extended Theory of Planned Behavior (ETPB): Investigating Customers' Perception of Restaurants' Sustainability by Testing a Structural Equation Model. Sustainability, 10(7), 2580.

Trafimow, D., \& Fishbein, M. (1994). The Moderating Effect of Behavior Type on the SN-Behavior Relationship. The Journal of Social Psychology, 134(6), 755-763.

Valente, T. W., \& Rogers, E. M. (1995). The Origins and Development of the Diffusion of Innovations Paradigm as an Example of Scientific Growth. Science Communication, 16(3), 242-273.

Venkatesh, V. (2000). Determinants of Perceived Ease of Use: Integrating Control, Intrinsic Motivation, and Emotion into the Technology Acceptance Model. Information Systems Research, 11(4), 342-365.

Vogue Crafts and Design PVT Ltd. (2019). Latest Imitation jewelry trends in the Jewelry industry. Retrieved from https://www.voguecrafts.com/story/single/latest-imitation-jewelry-trends-in-the-je w elry -industry

Workman, J. E., \& Caldwell, L. F. (2007). Centrality of visual product aesthetics, tactile and uniqueness needs of fashion consumers. International Journal of Consumer Studies, 31(6), 589-596.

Zhang, B., \& Kim, J.-H. (2013). Luxury fashion consumption in China: Factors affecting attitude and purchase intent. Journal of Retailing and Consumer Services, 20(1), 68-79. 